\title{
Enhanced Photocatalytic Activity of Ficus elastica Mediated Zinc Oxide-Zirconium Dioxide Nanocatalyst at Elevated Calcination Temperature: Physicochemical Study
}

\author{
Sirajul Haq ${ }^{1, *}$, Humma Afsar ${ }^{1}$, Israf Ud Din ${ }^{2}$, Pervaiz Ahmad ${ }^{3}{ }^{(D}$, Mayeen Uddin Khandaker $^{4}(\mathbb{D}$, \\ Hamid Osman ${ }^{5}$ D, Sultan Alamri ${ }^{5}$, Muhammad Imran Shahzad ${ }^{6}$, Nadia Shahzad ${ }^{7}$ D, Wajid Rehman ${ }^{8}$ \\ and Muhammad Waseem ${ }^{9}$
}

Citation: Haq, S.; Afsar, H.; Din, I.U. Ahmad, P.; Khandaker, M.U.; Osman, H.; Alamri, S.; Shahzad, M.I.; Shahzad, N.; Rehman, W.; et al. Enhanced Photocatalytic Activity of Ficus elastica Mediated Zinc Oxide-Zirconium Dioxide Nanocatalyst at Elevated Calcination Temperature: Physicochemical Study. Catalysts 2021, 11, 1481. https:// doi.org/10.3390/catal11121481

Academic Editor: Roberto Fiorenza

Received: 20 October 2021

Accepted: 23 November 2021

Published: 3 December 2021

Publisher's Note: MDPI stays neutral with regard to jurisdictional claims in published maps and institutional affiliations.

Copyright: (C) 2021 by the authors Licensee MDPI, Basel, Switzerland. This article is an open access article distributed under the terms and conditions of the Creative Commons Attribution (CC BY) license (https:// creativecommons.org/licenses/by/ $4.0 /)$.
1 Department of Chemistry, University of Azad Jammu and Kashmir, Muzaffarabad 13100, Pakistan; humma.afsar.mphil@ajku.edu.pk

2 Department of Chemistry, College of Science and Humanities, Prince Sattam Bin Abdulaziz University, P.O. Box 173, Al-Kharj 11942, Saudi Arabia; i.din@psau.edu.sa

3 Department of Physics, University of Azad Jammu and Kashmir, Muzaffarabad 13100, Pakistan; pervaiz_pas@yahoo.com

4 Center for Applied Physics and Radiation Technology, School of Engineering and Technology, Sunway University, Bandar Sunway 47500, Malaysia; mayeenk@sunway.edu.my

5 Department of Radiological Sciences, College of Applied Medical Sciences, Taif University, Taif 21944, Saudi Arabia; ha.osman@tu.edu.sa (H.O.); s.alamri@tu.edu.sa (S.A.)

6 National Center for Physics (NCP), Nanosciences and Technology Department (NS \& TD), Islamabad 44000, Pakistan; imrans@ncp.edu.pk

7 US-Pakistan Centre for Advanced Studies in Energy, National University of Science and Technology (NUST), Islamabad 44000, Pakistan; nadia@uspcase.nust.edu.pk

8 Department of Chemistry, Hazara University, Mansehra 21300, Pakistan; wajid757@hu.edu.pk

9 Department of Chemistry, COMSATS University Islamabad (CUI), Islamabad 45550, Pakistan; m.waseem@comsats.edu.pk

* Correspondence: siraj.ulhaq@ajku.edu.pk

Abstract: The photocatalytic degradation of Rhodamine 6G dye was achieved using a Ficus elastica (F. elastic) leaf extract mediated zinc oxide-zirconium dioxide nanocatalyst $\left(\mathrm{ZnO}-\mathrm{ZrO}_{2} \mathrm{NC}\right)$ under stimulated solar light, resulting in a substantial increase in photocatalytic activity at the highest calcination temperature. The crystal phase and crystallite size were determined using an X-ray diffractometer (XRD), and the degree of crystallinity was observed to rise with increasing calcination temperature. Energy dispersive X-ray (EDX) was used to investigate the elemental composition and purity of $\mathrm{ZnO}-\mathrm{ZrO}_{2} \mathrm{NC}$. Scanning electron microscopy (SEM) was used to investigate the surface morphology, and the morphological characteristics were altered when the calcination temperature was varied. For the $\mathrm{ZnO}-\mathrm{ZrO}_{2} \mathrm{NC}$ calcined at $100,300,600$, and $900{ }^{\circ} \mathrm{C}$, the average grain size determined from SEM images is $79.56 \mathrm{~nm}, 98.78$ (2) nm, 54.86 (2) nm, and 67.43 (2) nm, respectively. Using diffuse reflectance spectroscopy (DRS) data, the optical band gap energy was calculated using a Tauc's plot. The $\mathrm{ZnO}$ in $\mathrm{ZnO}-\mathrm{ZrO}_{2} \mathrm{NC}$ calcined at $100,300,600$, and $900{ }^{\circ} \mathrm{C}$ had band gap energies of 3.31, 3.36, 3.38, and $3.29 \mathrm{eV}$. Similarly, $\mathrm{ZrO}_{2}$ in $\mathrm{ZnO}-\mathrm{ZrO}_{2} \mathrm{NC}$ calcined at 100, 300,600 , and $900{ }^{\circ} \mathrm{C}$ had band gap energies of 3.96, 3.99, 3.97, and $4.01 \mathrm{eV}$, respectively. Fourier transform infrared (FTIR) spectroscopy was used to identify the presence of various functional groups. The photocatalytic activity was also examined in relation to calcination temperature, $\mathrm{pH}$, starting concentration, and catalyst dosage. Enhanced photocatalytic activity was observed at $\mathrm{pH} 11$ and 15 ppm initial concentration with a catalyst dose of $25 \mathrm{mg}$. The photocatalytic activity of the sample calcined at $900{ }^{\circ} \mathrm{C}$ was the highest, with 98.94 percent of the dye mineralized in $330 \mathrm{~min}$ at a degradation rate of $0.01261 / \mathrm{min}$.

Keywords: green synthesis; zinc oxide-zirconium dioxide; calcination; photocatalysis; rhodamine 6G 


\section{Introduction}

Environmental pollution has become a serious problem concerning to human health [1]. Paper, pulp, paint, varnishes, dyeing, petrochemical, cosmetics, ink, plastics, and textiles industries are releasing pollutants which affect the surrounding ecosystem [2]. During the process of dyeing, a large amount of dye is wasted and dumped into water. The industrial wastewater contains pathogens, agricultural and nutrients runoff, and organic and inorganic pollutants [3]. The wastewater which comes from the textile industries has a strong color and contains heavy metals, high concentrations of organic compounds, high $\mathrm{pH}$, and high chemical oxygen demand [4]. Organic dyes are commonly used in today's industry which have become a main source to create hazardous water pollutants [5]. These organic dyes are hazardous, toxic, carcinogenic, and badly affect the environment, human health, and aquatic ecosystems [2]. Several methods, such as ozonation, oxidation process, adsorption, ion exchange, membrane filtration, photocatalytic degradation, catalytic reduction, dialysis, and electrolysis, have been employed for the removal of dyes and other pollutants [5-7]. Photocatalysis is more appropriate method for the degradation of organic dyes due to eco-friendly and cost effect nature [8].

Transition metal oxides, metal-organic frameworks, and chalcogenides have been reported for photocatalytic degradation [9]. The semiconductor-assisted photocatalysis process has proven to be effective for the decomposition of organic pollutants found in wastewater, such as acids, dyes, and aromatic and phenolic compounds, due to its strong redox potential, environmental friendliness, moderate operation temperature, ease of operation, and useful final products [10]. Several attempted have been made to formulate highly stable and economical visible light driven photocatalysts with amendable band structure and low toxicity [11]. Binary nanocomposites of metal oxides increase the photodegradation efficiency as compared to individual metal oxide nanoparticles [12]. Silver and gold nanoparticles, $\mathrm{NO}_{3} / \mathrm{TiO}_{2}$ photoelectrodes, FePt-Ag nanocatalyst, and silver decorated magnetic nanocomposites were recently used as organic dyes reducing catalysts $[1,4,13]$. The $\mathrm{ZnO} / \mathrm{TiO}_{2} \mathrm{NC}$ showed enhanced solar light-induced photocatalytic activity against brilliant green and methylene blue, whereas its activity was higher than the individual $\mathrm{ZnO}$, $\mathrm{TiO}_{2}$, and P-25 against 4-chlorophenol under low UV light. The chemically synthesized $\mathrm{ZnO}-\mathrm{ZrO}_{2} \mathrm{NC}$ was used for the degradation of phenol, where activity was found to be higher than both the counterparts, and the activity also increased with the increasing $\mathrm{ZnO}$ in the sample. The $\mathrm{ZnO}$ and $\mathrm{ZrO}_{2}$ are more focused due to the high stability, wide absorption range, and boosted oxidation property. $\mathrm{ZnO}$ is commonly used as a photocatalytic material due to its non-toxic nature and high thermal and chemical stability [14]. $\mathrm{ZrO}_{2}$ is also used in photocatalytic reactions due to its low cost, re-useability, non-toxicity, excellent thermal stability, and inertness [15]. Binary composites of $\mathrm{ZrO}_{2}$ and $\mathrm{ZnO}$ have recently been utilized for organic pollutant degradation, and enhanced photocatalytic activity has been connected to changes in their textural, structural, and optical characteristics. Additionally, the enhanced electron hole pair improves photocatalytic efficiency [16]. Recently, $\mathrm{ZnO}-\mathrm{ZrO}_{2}$ was synthesized via sol-gel, chemical precipitation, and hydrothermal methods; however, no literature was found for the green synthesis of $\mathrm{ZnO}-\mathrm{ZrO}_{2}$ [17]. So far, very limited data have been reported on the synthesized of $\mathrm{ZnO}-\mathrm{ZrO}_{2} \mathrm{NC}$ and their biological and photocatalytic applications. However, no literature was found on the plant mediated synthesis of $\mathrm{ZnO}-\mathrm{ZrO}_{2} \mathrm{NC}$ and the photocatalytic ability under several experimental condition. In addition, the effect of calcination temperature on the crystalline structure, composition, and photocatalytic action are yet to be reported.

In this study, the $\mathrm{ZnO}-\mathrm{ZrO}_{2} \mathrm{NC}$ was synthesized by using F. elastic leaves extract and were calcined at 300,600 , and $900{ }^{\circ} \mathrm{C}$. XRD, SEM, EDX, FTIR, and UV-Visible spectroscopy were used to investigate the structural characteristics. The photodegradation of Rhodamine 6G in its aqueous solution in the presence of artificial sunshine was achieved using synthesized pure and calcined $\mathrm{ZnO}-\mathrm{ZrO}_{2} \mathrm{NC}$. Mathematical formulae were utilized to calculate the degradation rate constant and \% degradation of the photocatalyzed process. 


\section{Results and Discussion}

\subsection{XRD Analysis}

The XRD diffractograms of $\mathrm{ZnO}-\mathrm{ZrO}_{2} \mathrm{NC}$ calcined at $100,300,600$, and $900{ }^{\circ} \mathrm{C}$ are given in Figure 1, which shows that the diffraction spectrum of $\mathrm{ZnO}-\mathrm{ZrO}_{2}$ calcined at $100{ }^{\circ} \mathrm{C}$ has no peak and are suggested to be amorphous. After increasing the temperature from 100 to $300{ }^{\circ} \mathrm{C}$, the diffraction bands appeared in the spectrum at 2-theta position with corresponding hkl planes are 31.90 (100), 34.52 (002), 36.35 (101), 47.71 (102), 56.73 (110), 63.01 (103), and 68.08 (112). All these peaks, along with hkl planes, were found to be similar with those reported in the JCPDS card 01-075-0576, assigned to hexagonal-shaped ZnO with space group P63mc and space number 186. The crystallite size calculated with respect to the most intense diffraction band at $36.35^{\circ}$ was $35.40 \mathrm{~nm}$ with a lattice strain of 0.313 percent. The length of three coordinates, i.e., a, b, and c, of orthorhombic $\mathrm{ZnO}$ was 3.2427, 3.2427 , and $5.1948 \AA$ Á along with $90^{\circ}$ of alpha and beta, and $120^{\circ}$ of gamma, respectively. No diffraction band was observed for $\mathrm{ZrO}_{2}$ in the XRD pattern of the $\mathrm{ZnO}-\mathrm{ZrO}_{2}$ calcined at $300{ }^{\circ} \mathrm{C}$, depicting the amorphous nature of $\mathrm{ZrO}_{2}$. The results were consistent with the previous data, where amorphous $\mathrm{ZrO}_{2}$ was reported [15]. The diffraction peaks in the spectrum obtained for $\mathrm{ZnO}-\mathrm{ZrO}_{2}$ calcined at $600{ }^{\circ} \mathrm{C}$ at a 2 theta positions were 31.90, 34.52, $36.35,47.71,56.73,63.01$, and 68.08, with corresponding miller indices (100), (002), (101), (102), (110), (103), and (112), respectively. All these bands were matched with reference card 01-075-0576 and were assigned to the hexagonal geometrical shape of $\mathrm{ZnO}$ (having the same lattice parameters as stated above) with a space group of P63mc and space number 186. Another set of diffraction peaks at the 2-theta position, along with hkl values, were 30.44 (101), 35.46 (110), 50.33 (112), and 60.51 (211), corresponding to the JCPDS card No. 01-079-1771. These bands confirmed the tetragonal geometry of $\mathrm{ZrO}_{2}$ with the space group and number of $\mathrm{P} 42 / \mathrm{nmc}$ and 137 , where $\mathrm{a}$ and $\mathrm{b}$ coordinates are of 3.5916 Á while coordinate c is equal to $5.1790 \AA$, where all the three angles are $90^{\circ}$. The crystallite size calculated for $\mathrm{ZnO}$ and $\mathrm{ZrO}_{2}$ crystals were 70.90 and $23.30 \mathrm{~nm}$, with 0.157 and 0.563 percent lattice strain, respectively. The $\mathrm{XRD}$ pattern of $\mathrm{ZnO}-\mathrm{ZrO}_{2}$ calcined at $900{ }^{\circ} \mathrm{C}$ possessed similar diffraction bands at almost the same 2-theta positions with corresponding hkl planes explains the hexagonal and tetragonal geometrical shape of $\mathrm{ZnO}$ and $\mathrm{ZrO}_{2}$. The crystallite size for the $\mathrm{ZnO}$ and $\mathrm{ZrO} 2$ in the $\mathrm{ZnO}-\mathrm{ZrO}_{2}$ sample calcined at $900{ }^{\circ} \mathrm{C} 105.83$ and $41.80 \mathrm{~nm}$ with 0.105 and 0.317 percent imperfection in the crystals, respectively. A third set of Bragg's reflections appeared in the diffractogram of $\mathrm{ZnO}-\mathrm{ZrO}_{2}$ calcined at $900{ }^{\circ} \mathrm{C}$ at $24.13,28.31,40.91,49.35,55.46$, and 66.52 were found to be similar, with bands reported in reference card No. 00-032-1482 assigned to an unknown crystal system of $\mathrm{ZnZrO}_{3}$ with a crystallite size of $59.42 \mathrm{~nm}$ and lattice strain of 0.239 percent. The three separate sets of diffraction bands in the spectra of $\mathrm{ZnO}-\mathrm{ZrO}_{2}$ calcined at 600 and $900{ }^{\circ} \mathrm{C}$ suggest the formation of hetero-structures. The intensity of diffraction peaks was seen to increase with increasing calcination temperature, revealing that the degree of crystallinity increased along with crystallite sizes. However, no shift was seen in the peak positions with increasing calcination temperature, suggesting that no phase transformation occurred. 


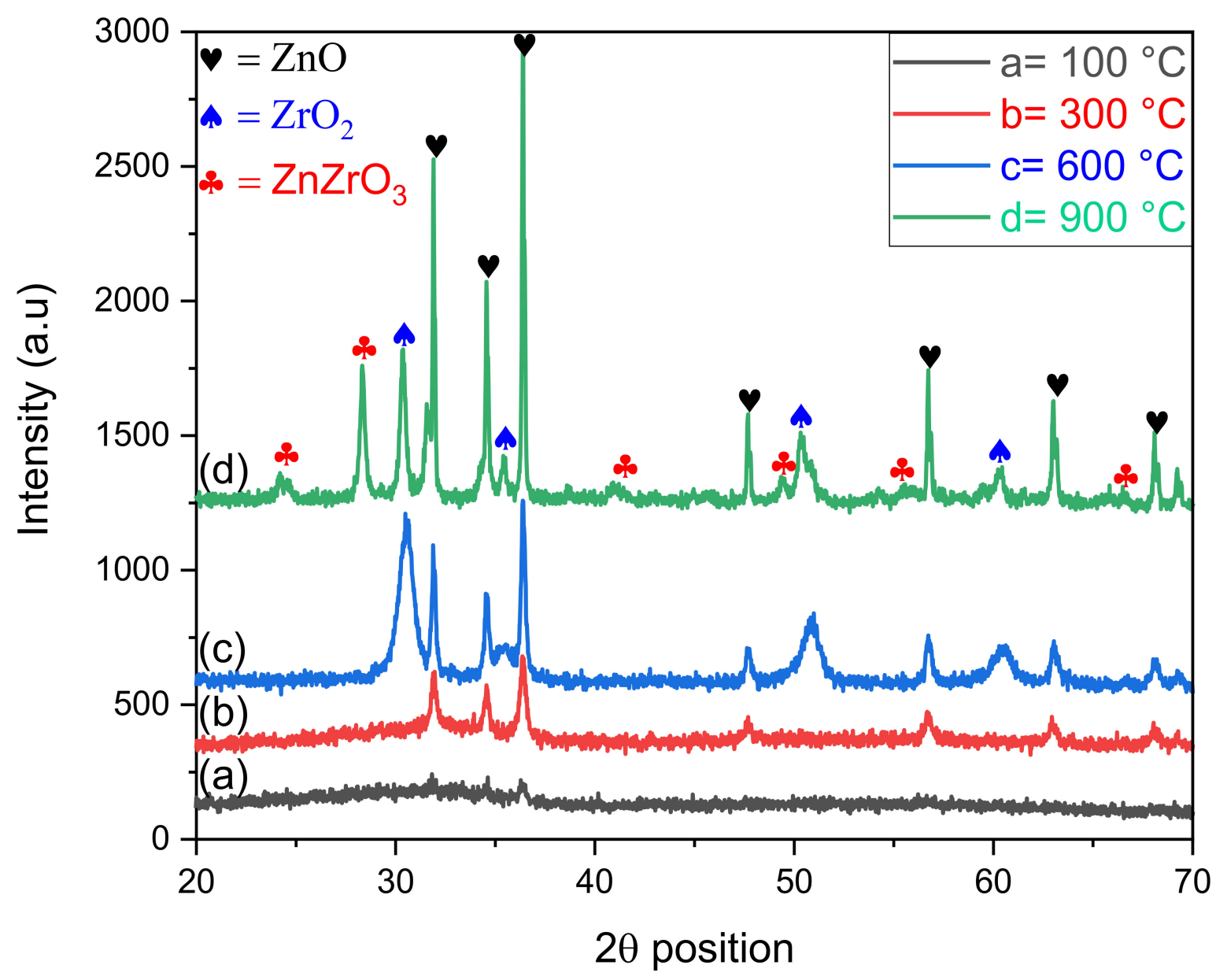

Figure 1. $\mathrm{XRD}$ patterns of $\mathrm{ZnO}-\mathrm{ZrO}_{2} \mathrm{NC}$ calcined at different temperature.

\subsection{SEM Analysis}

The morphology and grain size of all annealed $\mathrm{ZnO}-\mathrm{ZrO}_{2} \mathrm{NC}$ samples were measured using SEM and high magnification micrographics, as shown in Figure 2. The apparent borders between the grains vanish when the temperature rose from 100 to $300{ }^{\circ} \mathrm{C}$, indicating that a condensation process occurred, culminating in the development of a solid structure with the evaporation of water molecules. A further rise in calcination temperature up to $600{ }^{\circ} \mathrm{C}$ indicates the degeneration/cracking of solid structure resulted in the formation of granular samples (small sized particles) due to heat treatment. The SEM micrograph (Figure 2d) shows that due to the high surface energy, granules were recombined into small-large-sized grains when the temperature was increased from 600 to $900{ }^{\circ} \mathrm{C}$. Thus, the SEM analysis revealed that because of the change in calcination temperature, the phenomena of solidification/magnification, fragmentation, and coalescence occurred, steered to morphological changes. The average grain size determined from SEM images for the $\mathrm{ZnO}-\mathrm{ZrO}_{2} \mathrm{NC}$ calcined at $100,300,600$, and $900{ }^{\circ} \mathrm{C}$ was $79.56( \pm 3), 98.78( \pm 2)$, $54.86( \pm 2)$, and $67.43( \pm 2) \mathrm{nm}$, respectively. Grain sizes displayed anomalous behavior (decrease) after an unexpected rise in calcination temperature to $600{ }^{\circ} \mathrm{C}$. Increasing the calcination temperature, on the other hand, caused grain size to increase. Amorphous content conversion, dehydration, particle rearrangement, and phase transition are the most plausible causes of grain size variation with calcination temperature. An increase in grain size from 100 to $300^{\circ} \mathrm{C}$ may impede the calcination action of $\mathrm{ZnO}-\mathrm{ZrO}_{2} \mathrm{NC}$ powder due to enhanced conversion (condensation) from the amorphous to the crystalline phase. The compact solid deteriorated and a rough surface sample was generated as a result of 
increasing the calcination temperature to $600{ }^{\circ} \mathrm{C}$. An increase in the calcination temperature to $900{ }^{\circ} \mathrm{C}$ aided in the controlled nucleation and development of the $\mathrm{ZnO}-\mathrm{ZrO}_{2}$ grains.

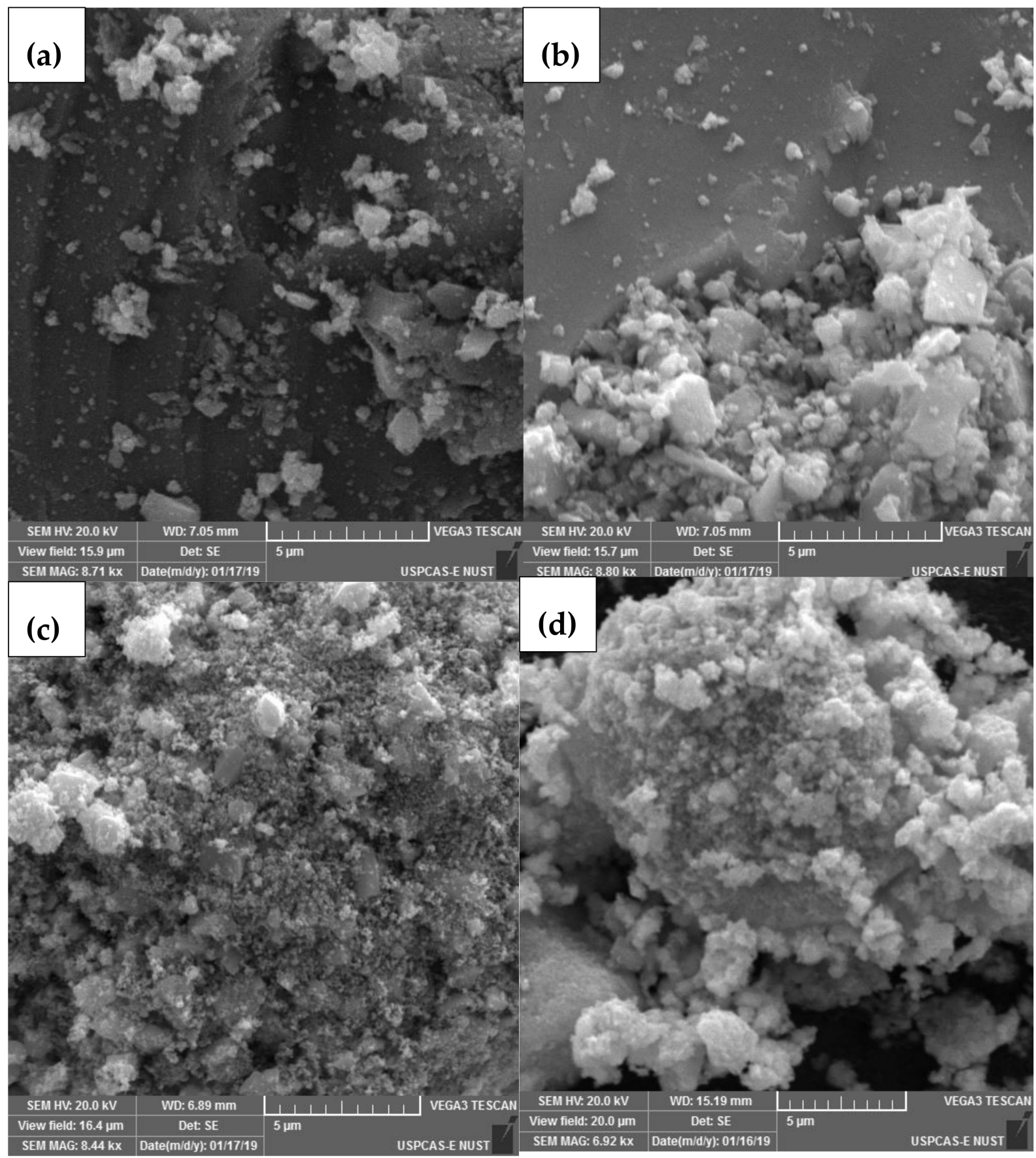

Figure 2. SEM Micrographs of $\mathrm{ZnO}-\mathrm{ZrO}_{2} \mathrm{NC}$ calcined at different temperature $\left((\mathbf{a})=100{ }^{\circ} \mathrm{C} ;(\mathbf{b})=300{ }^{\circ} \mathrm{C} ;(\mathbf{c})=600{ }^{\circ} \mathrm{C}\right.$; and (d) $=900^{\circ} \mathrm{C}$.).

\subsection{FTIR Analysis}

The wide band centred at $3429 \mathrm{~cm}^{-1}$ indicates the stretching vibration of the $\mathrm{OH}$ group, whereas the two peaks at 1649.14 and $1558.14 \mathrm{~cm}^{-1}$ indicate the bending vibrations of adsorbed water molecules and $\mathrm{OH}$ groups on the surface, respectively, in the FTIR spectra of $\mathrm{ZnO}-\mathrm{ZrO}_{2} \mathrm{NC}$ calcined at 100, 300, 600, and $900{ }^{\circ} \mathrm{C}$, as shown in Figure 3 [18,19]. The intensity at $1435.10 \mathrm{~cm}^{-1}$ was assigned to the carbon-carbon stretching of organic compounds, whereas the bands at 1235.39 and $1073.03 \mathrm{~cm}^{-1}$ indicate the bending vibrations 
of $\mathrm{C}-\mathrm{O}-\mathrm{C}$ and overlapping of $\mathrm{C}-\mathrm{O}$ groups, respectively, which might have been present in the sample due to the use of plant material in the synthesis $[13,20]$. The strength of the above peaks decreased as the calcination temperature increased from $300{ }^{\circ} \mathrm{C}$ to $900{ }^{\circ} \mathrm{C}$, which is due to the fact that water and other organic molecules evaporate at higher calcination temperatures. The bending vibrations of $\mathrm{M}-\mathrm{O}-\mathrm{H}$ bonds found on the surface groups were responsible for the band at around $1358.02 \mathrm{~cm}^{-1}$ [16]. The vibration modes of $\mathrm{Zr}-\mathrm{O}-\mathrm{Zr}$ and $\mathrm{O}-\mathrm{Zr}-\mathrm{O}$ appeared at 873.59 and $656.90 \mathrm{~cm}^{-1}$, respectively [16]. The wavenumber at $537.389 \mathrm{~cm}^{-1}$ is associated with the $\mathrm{Zn}-\mathrm{O}$ bond [18]. The band of $447.51 \mathrm{~cm}^{-1}$ confirmed the formation of crystalline $\mathrm{ZnO}-\mathrm{ZrO}_{2} \mathrm{NC}$ [20].

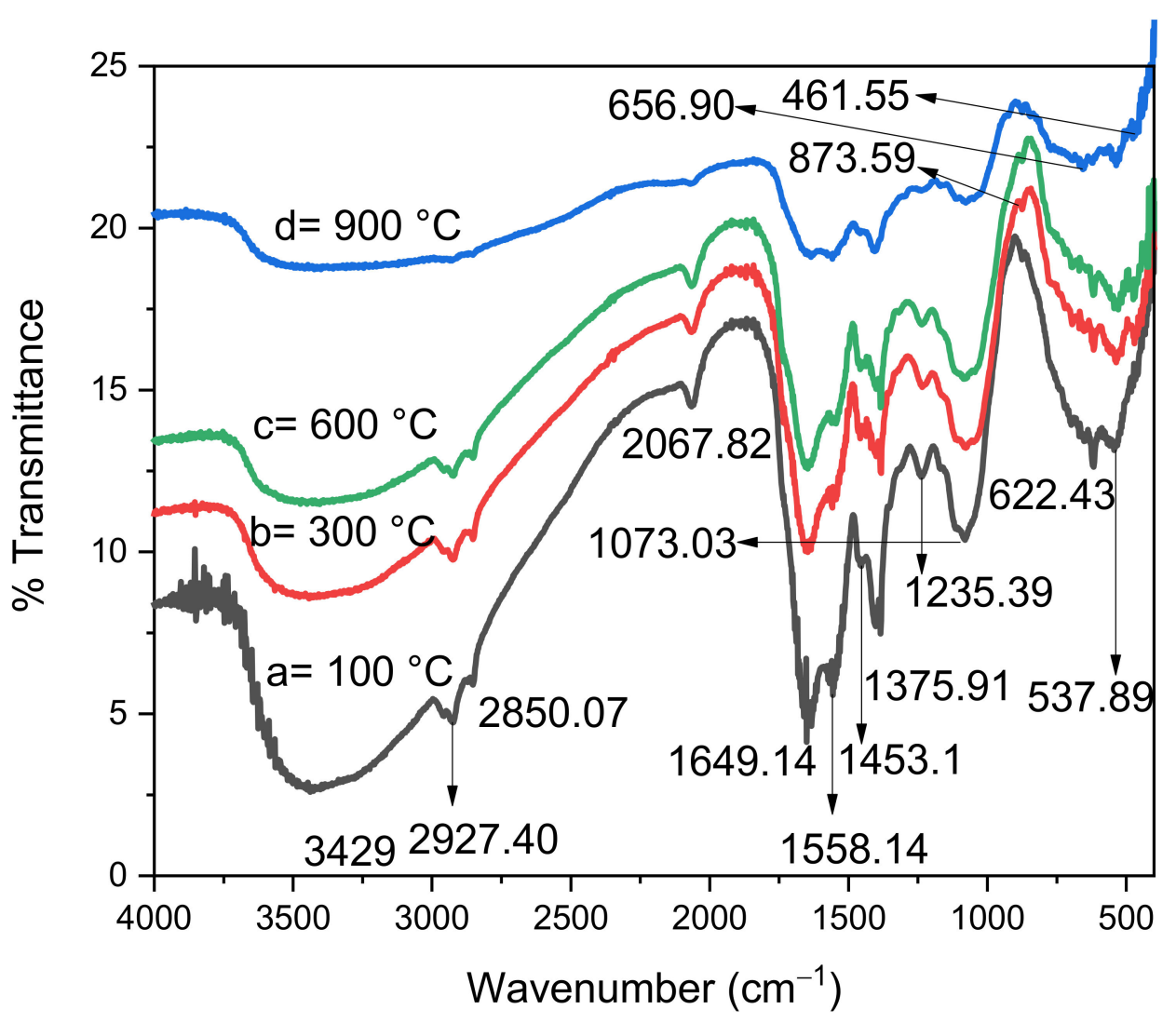

Figure 3. FTIR spectra of $\mathrm{ZnO}-\mathrm{ZrO}_{2} \mathrm{NC}$ calcined at different temperature.

\subsection{DRS Analysis}

We calculated the band gap energy, which was the lowest energy required for electron excitation from the valance band to the conduction band [21]. The DRS spectrum of $\mathrm{ZnO}-\mathrm{ZrO}_{2} \mathrm{NC}$ shows two absorption edges instead of one, suggesting the formation of $\mathrm{ZnO}-\mathrm{ZrO}_{2}$ heterojunction (Figure 4), as was also confirmed by XRD and FTIR analysis, where individual bands were seen for $\mathrm{ZnO}$ and $\mathrm{ZrO}_{2}$. The DRS spectra for all calcined $\mathrm{ZnO}-\mathrm{ZrO}_{2}$ samples shows an absorption band in the range of 353 to $370 \mathrm{~nm}$ attributed to the excitation of electron from valance band to conduction band $(\mathrm{O} 2 \mathrm{p} \rightarrow \mathrm{Zn} 3 \mathrm{~d})$. The spectrum also shows another absorption edge appeared at a lower wavelength in the range of 293-303 $\mathrm{nm}$ due to the presence of $\mathrm{Zr}$ in the form of $\mathrm{Zr}^{4+}$ and the excitation of an electron from the valance band $(\mathrm{O} 2 \mathrm{p})$ to the conduction band $(\mathrm{Zr} 4 \mathrm{~d})$. The absorption edges for $\mathrm{ZnO}$ and $\mathrm{ZrO}_{2}$ in the $\mathrm{ZnO}-\mathrm{ZrO}_{2}$ samples calcined at 100, 300, 600, and $900{ }^{\circ} \mathrm{C}$ were found to be in close agreement with reported data [14]. The presence of two edges can be seen for $\mathrm{ZnO}-\mathrm{ZrO}_{2}$ materials and a band gap can also be determined through a Tauc plot. All the calcined $\mathrm{ZnO}-\mathrm{ZrO}_{2} \mathrm{NC}$ revealed higher transmittance in the visible region and lower transmittance in the UV region [22,23]. The band gap energy for $\mathrm{ZnO}$ in 
$\mathrm{ZnO}-\mathrm{ZrO}_{2}$ heterojunction calcined at $100,300,600$, and $900{ }^{\circ} \mathrm{C}$ were $3.31,3.36,3.38$, and $3.29 \mathrm{eV}$, respectively. Similarly, the band gap energy for $\mathrm{ZrO}_{2}$ in $\mathrm{ZnO}-\mathrm{ZrO}_{2}$ heterojunction calcined at $100,300,600$, and $900{ }^{\circ} \mathrm{C}$ were $3.96,3.99,3.97$, and $4.01 \mathrm{eV}$.

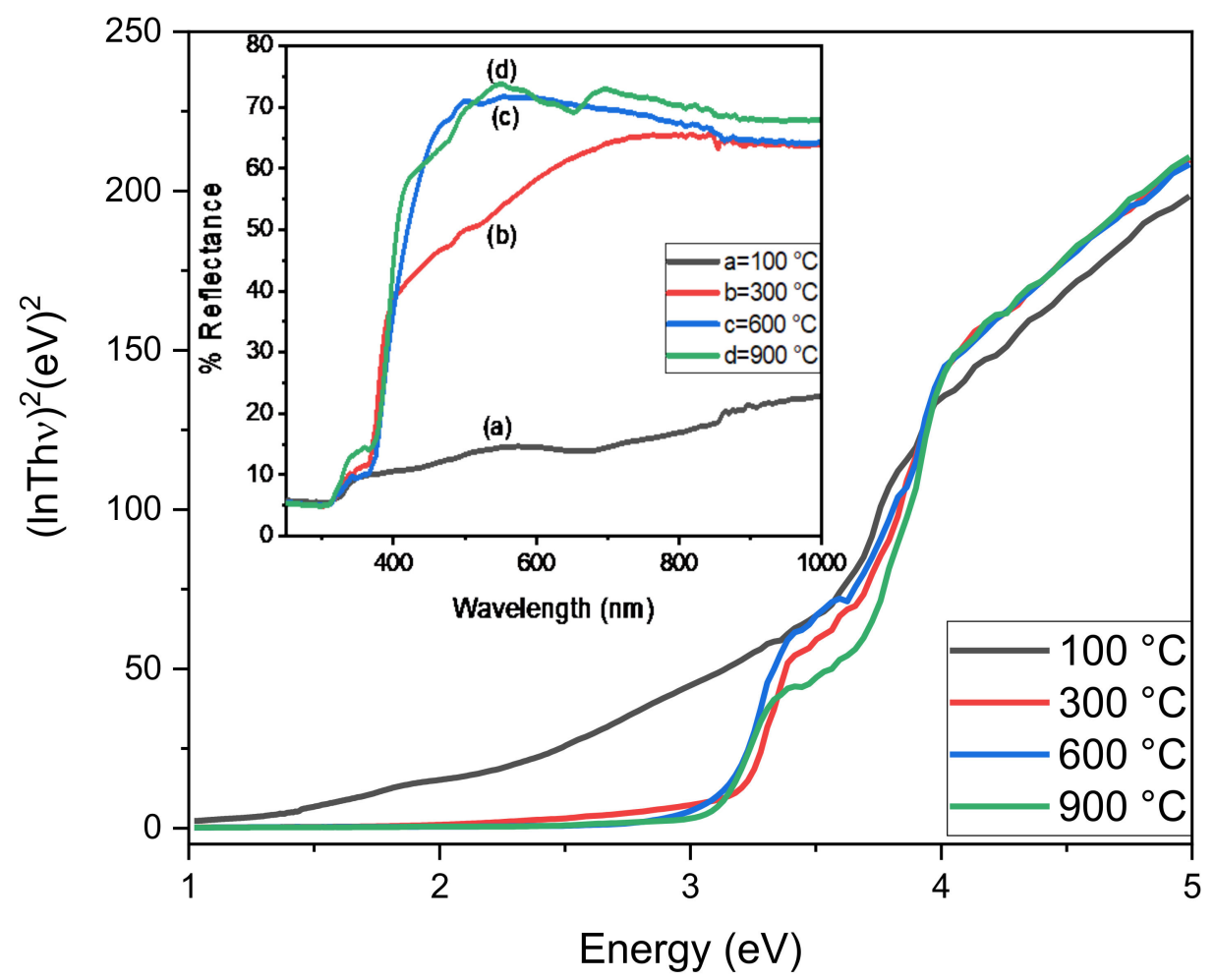

Figure 4. Tauc's plots (Inset: DRS spectra) of $\mathrm{ZnO}-\mathrm{ZrO}_{2} \mathrm{NC}$ calcined at different temperature.

\subsection{EDX Analysis}

As shown in Figure 5, the elemental composition and purity of the synthesized ZnO$\mathrm{ZrO}_{2} \mathrm{NC}$ were investigated using EDX. $\mathrm{Zn}$ is responsible for the sharp peaks at 1, 8.6, and $9.5 \mathrm{keV}$, whereas $\mathrm{Zr}$ is responsible for the peaks at 2, 2.5, 15.75, and $17.6 \mathrm{keV}$. The presence of a peak for $\mathrm{O}$ at $0.5 \mathrm{keV}$ suggests that zinc and zirconium oxides were formed. The other peaks at 0.2 and $0.3 \mathrm{keV}$ are due to $\mathrm{Cl}$ and $\mathrm{C}$, which were caused by the chloride salt of the precursor and the carbon tape used during the EDX analysis. $\mathrm{Zn}, \mathrm{Zr}, \mathrm{O}$, and $\mathrm{Cl}$ have weight percentages of $42.7,34.1,22.6$, and 0.4 percent, respectively. 


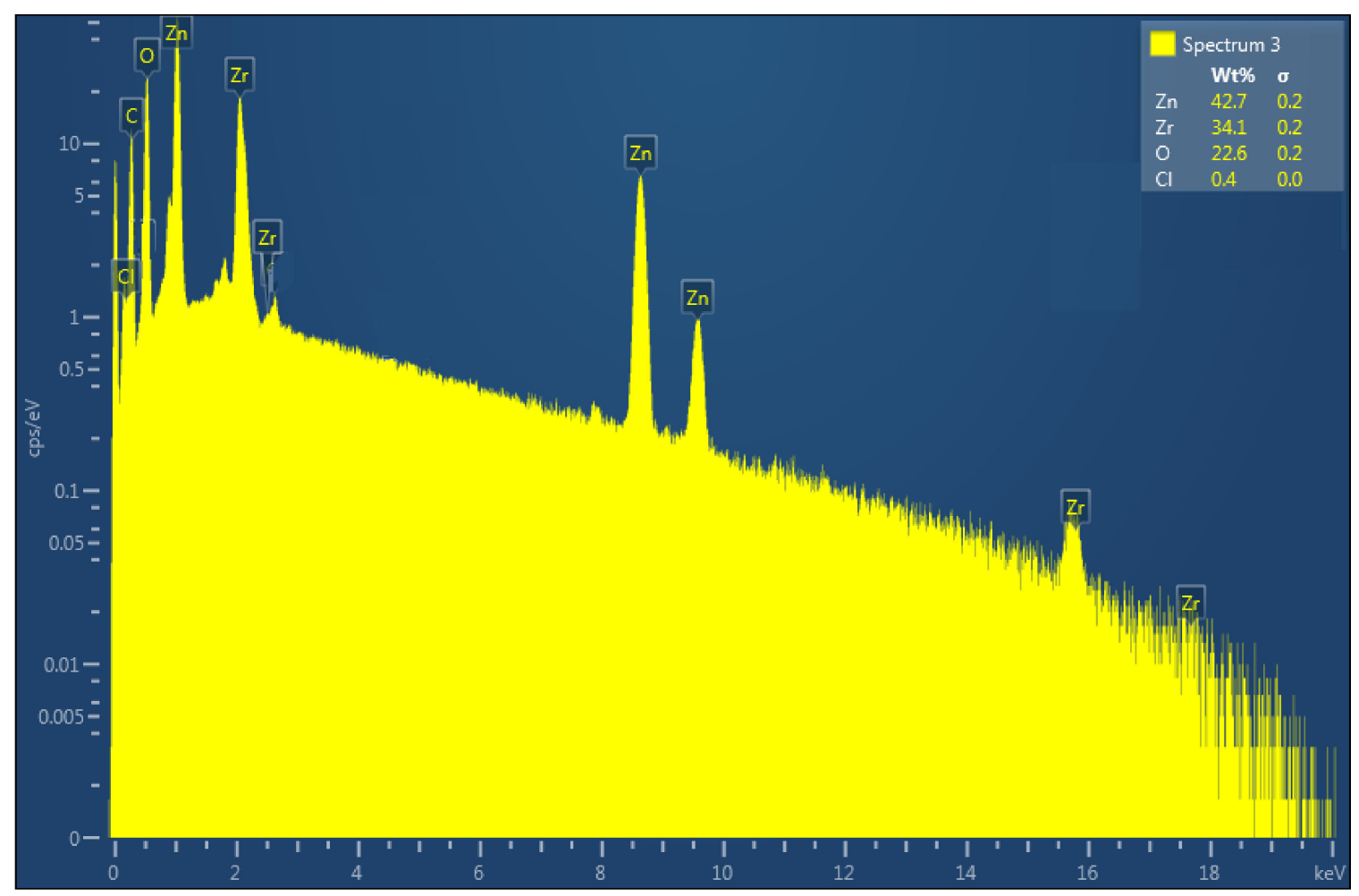

Figure 5. EDX spectrum of $\mathrm{ZnO}-\mathrm{ZrO}_{2} \mathrm{NC}$ calcined at $100{ }^{\circ} \mathrm{C}$.

\subsection{Photocatalytic Activity}

The photocatalytic degradation of Rhodamine $6 \mathrm{G}$ in the presence of stimulated solar light was demonstrated utilizing $\mathrm{ZnO}-\mathrm{ZrO}_{2} \mathrm{NC}$. The reaction mixture was agitated in the dark for $30 \mathrm{~min}$ before being exposed to stimulated solar light, and the changes in absorbance maxima were measured using a double beam spectrophotometer. After exposure to stimulated solar light, a decrease in absorbance maxima with respect to time was examined, as shown in Figure 6a. The \% degradation (as given in Figure 6b) and degradation rate constant (Figure 6c) of Rhodamine 6G were calculated by using Equations (1) and (2), (where $C_{o}$ is initial absorbance and $C_{t}$ is the absorbance after time $(\mathrm{t})$ ) respectively [24]. Where $C_{o}$ denotes the starting concentration, $C$ denotes the end concentration, $C_{t}$ is the concentration of Rhodamine $6 \mathrm{G}$ following exposure to stimulated solar radiation, and $\mathrm{k}$ denotes the reaction rate constant. The percentage degradation of Rhodamine $6 \mathrm{G}$ was recorded to be $98.39,97.78,96.71$, and 98.94 percent with the degradation rate constant of $0.0125,0.0099,0.00965$, and 0.01261 per min. Based on the photocatalytic potential, $\mathrm{ZnO}-\mathrm{ZrO}_{2} \mathrm{NC}$ calcined at $900{ }^{\circ} \mathrm{C}$ are the most efferent photocatalysts under the applied experimental condition. The stability of the $\mathrm{ZnO}-\mathrm{ZrO}_{2} \mathrm{NC}$ calcined at different temperatures was tested under the current experimental conditions five times, and after $330 \mathrm{~min}$, a fresh solution was added to the reactor. The same process was repeated five times for each calcined catalyst. The percent degradation recorded during stability test in the presence of $\mathrm{ZnO}-\mathrm{ZrO}_{2}$ calcined at $100{ }^{\circ} \mathrm{C}$ are $98.39,96.54,93.68,8.92$, and 84.46; for $\mathrm{ZnO}-\mathrm{ZrO}_{2}$ calcined at $300{ }^{\circ} \mathrm{C}$ are $97.78,96.04,92.30,87.76$, and 81.58 ; for $\mathrm{ZnO}-\mathrm{ZrO}_{2}$ calcined at $600{ }^{\circ} \mathrm{C}$ are 96.71 , $93.88,90.57,86.67$, and 79.02 and for $\mathrm{ZnO}-\mathrm{ZrO}_{2}$ calcined at $900{ }^{\circ} \mathrm{C}$ are $98.94,97.08,95.03$, 91.46, and $86.93 \%$ during 1st, 2nd, 3rd, 4th, and 5th cycles respectively. This shows the stability of the synthesized $\mathrm{ZnO}-\mathrm{ZrO}_{2} \mathrm{NC}$, and can be used for several-step degradation of organic pollutants. Based on the stability test, the catalysts calcined at $900{ }^{\circ} \mathrm{C}$ are more stable followed by the one calcined at $100{ }^{\circ} \mathrm{C}$, whereas the $\mathrm{ZnO}-\mathrm{ZrO}_{2}$ calcined at $600{ }^{\circ} \mathrm{C}$ is the least stable among these catalysts. 

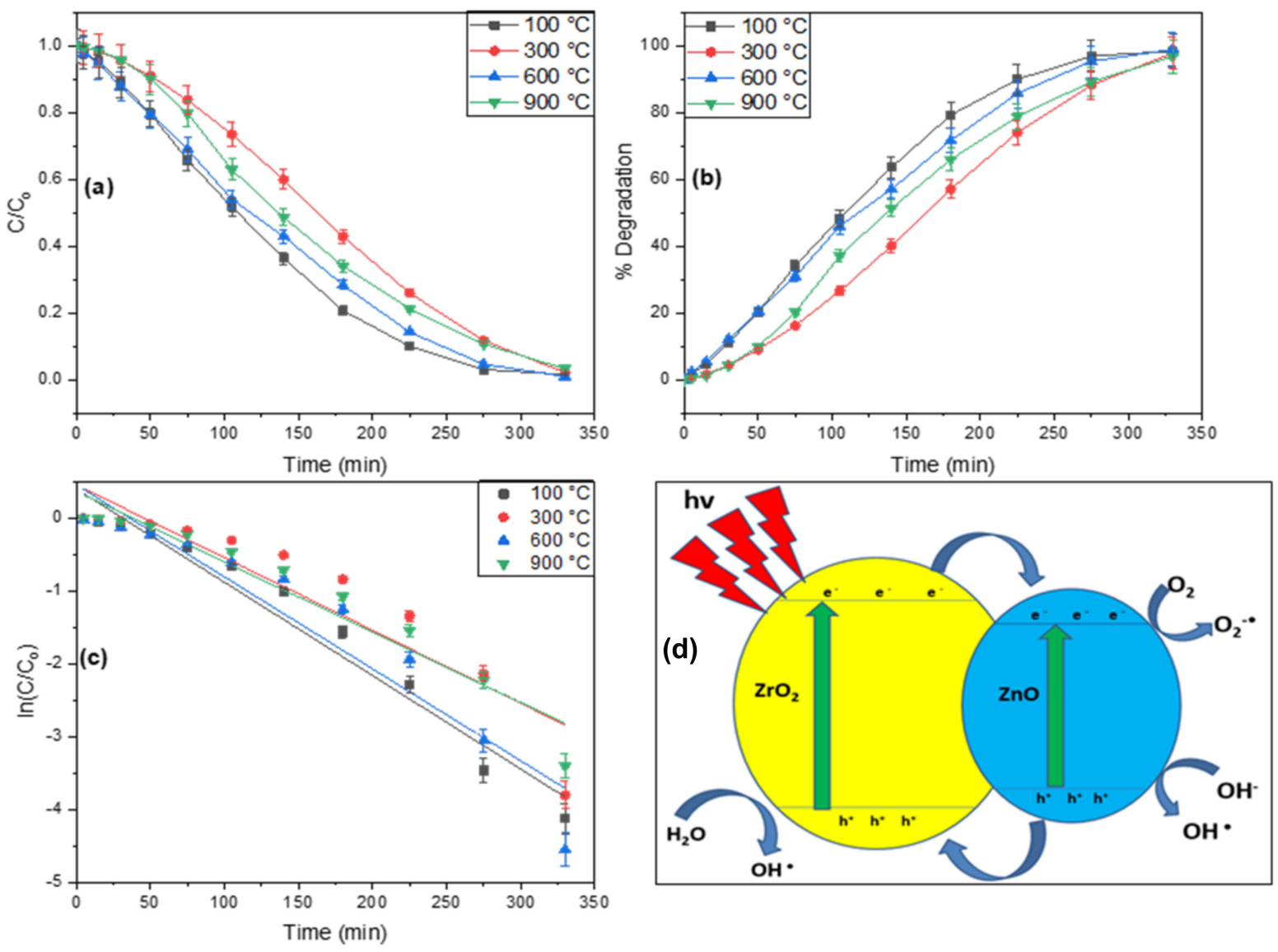

Figure 6. The photocatalytic degradation of rhodamine 6G; (a) degradation profile, (b) percent degradation, (c) kinetic plots, and (d) schematic diagram representing excitation of electron and hole creation.

On the basis of available literature, the photocatalytic efficiency of $\mathrm{ZnO}, \mathrm{ZrO}_{2}$, and $\mathrm{ZnO}-\mathrm{ZrO}{ }_{2}$ nanostructures was compared as shown in Table 1 . The reported data clearly shows that the $\mathrm{ZnO}-\mathrm{ZrO}_{2} \mathrm{NC}$ exhibits significantly enhanced photocatalytic activity against different organic pollutants, which might be due to the synergistic effect of both counterparts.

$$
\begin{gathered}
\text { \% degradation }=\frac{C_{o}-C_{t}}{C_{o}} \times 100 \\
\ln \left(\frac{C}{C_{o}}\right)=-k t
\end{gathered}
$$

In the presence of a stimulated solar light source, $\mathrm{ZnO}-\mathrm{ZrO}_{2} \mathrm{NC}$ destroys Rhodamine 6G. When photons of light reach the surface of the catalyst, an outermost electron is activated. The excited electron oxidizes the oxygen in the reaction mixture, forming an oxygen anion radical. To breakdown the dye, the oxygen ion radical interacts with Rhodamine 6G and transforms it into a simpler organic molecule [21,25]. A schematic diagram for the degradation of Rhodamine 6G is shown in Figure 6d. When the $\mathrm{ZnO}-\mathrm{ZrO}_{2}$ $\mathrm{NC}$ is activated by solar light, electrons migrate from the valence bands of both oxides to the conduction band, forming electron-hole pairs. Because the energy levels of zinc oxide fit nicely within the band gap of $\mathrm{ZrO}_{2}$, electrons from the conduction band of zirconium dioxide may readily migrate to the conduction band of $\mathrm{ZnO}$ [26]. On the other hand, holes move from the valence band of $\mathrm{ZnO}$ to the valence band of $\mathrm{ZrO}_{2}$, potentially reducing electron-hole pair recombination in $\mathrm{ZnO}-\mathrm{ZrO}_{2} \mathrm{NC}$. These $\mathrm{e}^{-}$and $\mathrm{h}^{+}$radicals react with 
oxygen and water to create $(\mathrm{OH} \bullet)$ radicals, which may quickly oxidize Rhodamine 6G due to their high reactivity and production of water and carbon dioxide [27].

Table 1. Photocatalytic efficiency of $\mathrm{ZnO}, \mathrm{ZrO}_{2}$ and $\mathrm{ZnO}-\mathrm{ZrO}_{2}$ nanostructures against different organic pollutants.

\begin{tabular}{|c|c|c|c|c|c|c|c|}
\hline \multirow[b]{2}{*}{ Dye } & \multicolumn{2}{|c|}{$\mathrm{ZnO}$} & \multicolumn{2}{|c|}{$\mathrm{ZrO}_{2}$} & \multicolumn{2}{|c|}{$\mathrm{ZnO}-\mathrm{ZrO}_{2}$} & \multirow[b]{2}{*}{ References } \\
\hline & $\begin{array}{c}\% \\
\text { Degradation }\end{array}$ & $\begin{array}{l}\text { Time } \\
\text { (min) }\end{array}$ & $\begin{array}{c}\% \\
\text { Degradation }\end{array}$ & $\begin{array}{l}\text { Time } \\
\text { (min) }\end{array}$ & $\begin{array}{c}\% \\
\text { Degradation }\end{array}$ & $\begin{array}{l}\text { Time } \\
\text { (min) }\end{array}$ & \\
\hline Methyl orange & 99.55 & 80 & 99 & 110 & \multicolumn{2}{|c|}{ No literature found } & {$[28,29]$} \\
\hline Phenol & 74 & 120 & 78 & 320 & 89 & 120 & {$[15,30]$} \\
\hline Congo red & 30 & 11 & 98 & 125 & 90 & 120 & {$[31,32]$} \\
\hline Methylene blue & 87 & 90 & 11 & 70 & 97 & 30 & [15] \\
\hline 2-Chlorophenol & 61 & 60 & 51 & 240 & \multicolumn{2}{|c|}{ No literature found } & {$[33,34]$} \\
\hline Rhodamine 6G & 55.51 & 180 & No literatı & und & 98.94 & 330 & $\begin{array}{l}\text { [35] and } \\
\text { present study }\end{array}$ \\
\hline
\end{tabular}

\subsection{Factors Affecting the Photocatalytic Activity}

The parameters like initial concentration, catalyst dose, $\mathrm{pH}$, and calcination temperature greatly affect the photocatalytic activity of the $\mathrm{ZnO}-\mathrm{ZrO}_{2} \mathrm{NC}$ and obtained data is depicted in Figure $7 \mathrm{a}-\mathrm{d}$. This effect is briefly explained below:
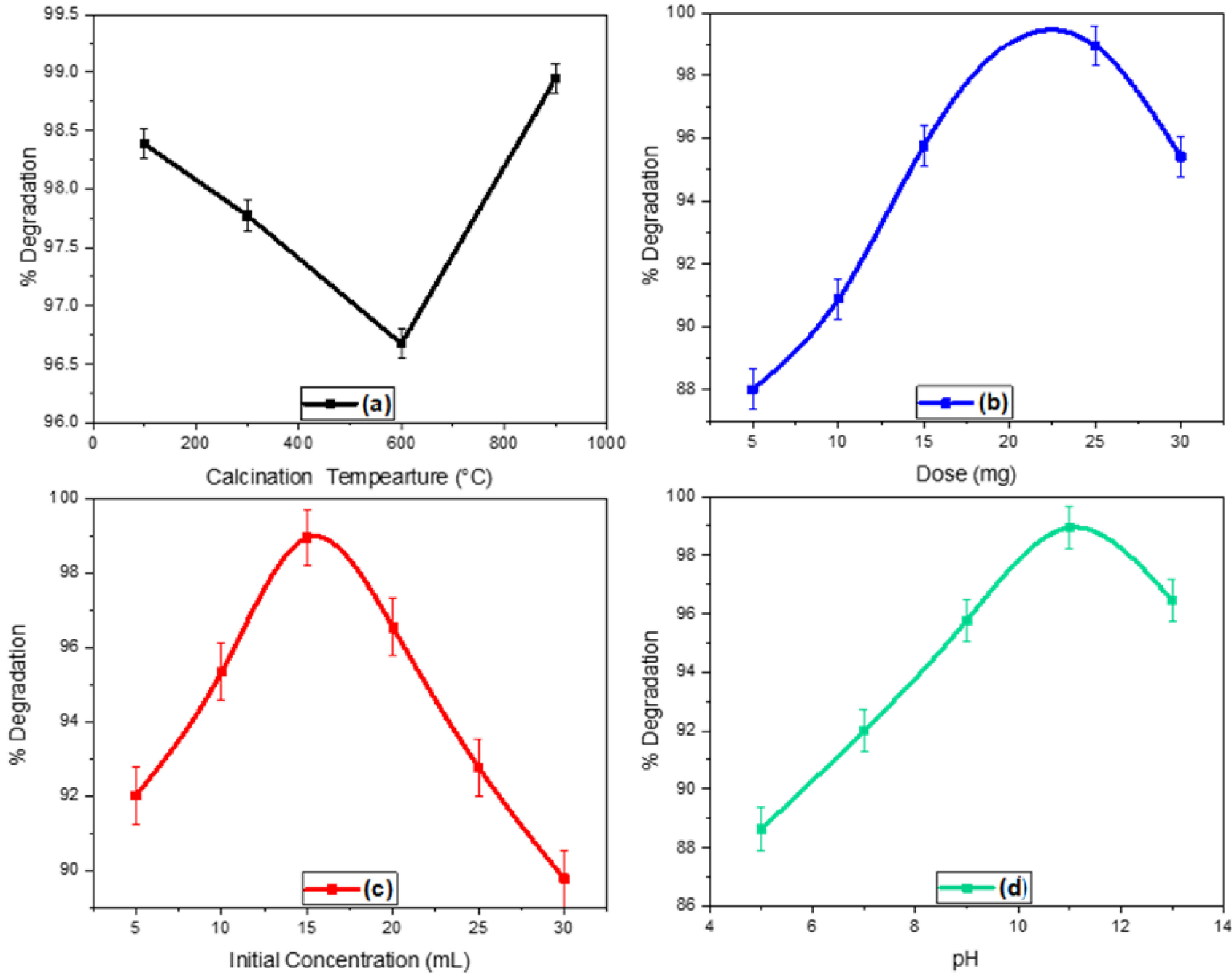

Figure 7. The factors effecting photocatalytic degradation of rhodamine 6G; (a) effect of temperature, (b) effect of catalyst dose, (c) effect of initial concentration, and (d) effect of $\mathrm{pH}$. 


\subsubsection{Effect of Calcination Temperature}

The synthesized $\mathrm{ZnO}-\mathrm{ZrO}_{2} \mathrm{NC}$ was calcined at $100,300,600$, and $900{ }^{\circ} \mathrm{C}$ and the effect of calcination temperature was examined on the photocatalytic degradation of Rhodamine 6G. As studied in the XRD and SEM analysis, the sample phase and morphological parameters were constantly changed with increasing calcination temperature, which has a great influence on the photocatalytic efficacy of the $\mathrm{ZnO}-\mathrm{ZrO}_{2} \mathrm{NC}$. With increasing calcination temperature, a regular decrease in the photocatalytic activity was seen, which might be due to the transformation of the amorphous phase into the crystalline phase. The maximum photocatalytic activity was experienced for the sample calcined at $900{ }^{\circ} \mathrm{C}$, where almost 98.94 percent of the dye was degraded in $330 \mathrm{~min}$, where the maximum amount of the $\mathrm{ZnO}-\mathrm{ZrO}_{2} \mathrm{NC}$ was converted into crystalline form. Moreover, the sample calcined at $900{ }^{\circ} \mathrm{C}$ contained three type species like $\mathrm{ZnO}, \mathrm{ZrO}_{2}$, and $\mathrm{ZnZrO}_{3}$ (XRD analysis), which might have a potential effect on the photodegradation of Rhodamine 6G [36].

\subsubsection{Effect of Catalyst Dose}

Different quantities of $\mathrm{ZnO}-\mathrm{ZrO}_{2} \mathrm{NC}$ (i.e., 5, 10, 15, 20, 25, and $30 \mathrm{mg}$ ) were used to investigate the effect of the catalyst on the photo-induced mineralization of Rhodamine 6G. A gradual increase in the photocatalytic activity was observed with the increase in the catalyst amount up to $25 \mathrm{mg}$, whereas a steady decrease was observed upon further increase of the catalyst. The increase in the degradation process is credited to the formation of active sites that promote degradation, whereas the quantity of catalyst more than $25 \mathrm{mg}$ blocks the penetration of light, thus reducing the photodegradation of the dye [37].

\subsubsection{Effect of Initial Concentration of Dye}

In the present study, different concentrations of Rhodamine 6G (i.e., 5, 10, 15, 20, 25 , and $30 \mathrm{ppm}$ ) were exposed to $25 \mathrm{mg}$ of $\mathrm{ZnO}-\mathrm{ZrO}_{2} \mathrm{NC}$ to scrutinize the effect of the initial concentration of the dye on its degradation. The results showed that the maximum degradation was seen at $15 \mathrm{ppm}$, where the concentration above $15 \mathrm{ppm}$ results in a clear decrease in the degradation of Rhodamine 6G. This decrease in the degradation can be attributed to the phenomenon that at high initial concentration of the dye, maximum light is absorbed by the dye molecules rather than the photocatalysts, consequently reducing the degradation [38].

\subsubsection{Effect of $\mathrm{pH}$}

To test the influence of $\mathrm{pH}$ on Rhodamine $6 \mathrm{G}$ degradation, $25 \mathrm{mg}$ of $\mathrm{ZnO}-\mathrm{ZrO}_{2} \mathrm{NC}$ was introduced to eight reaction vessels containing $50 \mathrm{~mL}$ of dye solution ( $15 \mathrm{ppm}$ ) each, while all other reaction conditions remained constant throughout the experiment. According to the findings, the greatest degradation occurred at $\mathrm{pH} 11$. This demonstrates that the $\mathrm{pH}$ values have a significant impact on the photocatalytic degradation of Rhodamine 6G. The production of hydroxyl radicals (powerful oxidizing agents) that contribute to the degradation of Rhodamine 6G causes the greater degradation in the basic media [39].

\section{Materials and Methods}

\subsection{Materials}

The chemicals required for this study included zircon (IV) chloride, zinc chloride, sodium hydroxide, and Rhodamine 6G were purchased from Sigma-Aldrich, St. Louis, $\mathrm{MO}$, USA. The F. elastic leaves were collected, and their aqueous extract was used as a reducing and capping agent for the synthesis of $\mathrm{ZnO}-\mathrm{ZrO}_{2} \mathrm{NC}$.

\subsection{Preparation of F. Elastic Leaves Extract}

The F. elastic leaves were collected and washed with tap water to get rid of dust particles, followed by distilled water to purify and kept for drying. Fifty grams of dried leaves were placed in a beaker with $1000 \mathrm{~mL}$ of distilled water and heated until a thick 
green color appeared. The F. elastic leaves extract was filtered and centrifuged for $20 \mathrm{~min}$ at $4000 \mathrm{rpm}$ before storing the top clear layer at room temperature.

\subsection{Synthesis of $\mathrm{ZnO}-\mathrm{ZrO}_{2} \mathrm{NC}$}

Nanoparticles of $\mathrm{ZrO}_{2}$ and $\mathrm{ZnO}$ were prepared by individual mixing of $50 \mathrm{~mL}$ of zircon (IV) chloride $(1.28 \mathrm{~g})$ and zinc chloride $(1.05 \mathrm{~g})$ solution with $20 \mathrm{~mL}$ of the prepared extract agitated at $70{ }^{\circ} \mathrm{C}$. The $\mathrm{pH}$ of both reactions was fixed at 10 by the addition of $\mathrm{NaOH}$ solution and constantly heated and stirred for $30 \mathrm{~min}$, and the obtained precipitate was aged for 5 hours. To eliminate the chloride ion and other contaminants, the precipitates were washed three times with distilled water and dried in an oven at $100{ }^{\circ} \mathrm{C}$.

Next, both the $\mathrm{ZrO}_{2}$ and $\mathrm{ZnO}$ NPs were dissolved in 30\% (v:v) nitric acid individually and mixed together at $70{ }^{\circ} \mathrm{C}$ with vigorous stirring. The $\mathrm{NaOH}$ solution was added to get the $\mathrm{pH}$ up to 10, and the mixture was continually agitated for 6 hours. The finished product was cleaned four times with distilled water before being dried overnight at $100{ }^{\circ} \mathrm{C}$ in an oven. Using a pestle and mortar, the dry product was crushed into fine powder and stored in a plastic bottle. The whole procedure was repeated until the desired amount of product was obtained. The product was then calcined at 300,600 , and $900{ }^{\circ} \mathrm{C}$ for $3 \mathrm{~h}$ in a muffle furnace, respectively.

\subsection{Characterization}

The physicochemical properties such as the crystal structure, surface morphology, crystal size, and percent composition of the synthesized sample were characterized by using XRD, SEM, EDX, DRS, and FTIR spectroscopy. The Debye-Scherrer equation was used to compute the crystallite size of the $\mathrm{ZnO}-\mathrm{ZrO}_{2} \mathrm{NC}$, and the crystalline nature was examined using the XRD model Philips X'Pert PW 3040, manufactured by CAE, Montreal, Canada. The microstructure and surface topology were investigated using a SEM model JEOL JSM-5600LV (made in Tokyo, Japan). An energy-dispersive X-ray (EDX) examination was done with a JEOL JSM-5600LV (made in Tokyo, Japan) combined with a scanning electron microscope (SEM) to confirm the sample's composition, while surface functional moieties were investigated using an FTIR model Nicolet 560 (Thermo Fisher Scientific Waltham, MA, USA) operating in the $4000-400 \mathrm{~cm}^{-1}$ range. The transmittance edge was measured using a DRS analysis was carried out by DRS (Thermo Fisher Scientific Waltham, MA, USA) in the range of 200-1000 $\mathrm{nm}$, and the band gap energy was estimated using a Tauc's plot.

\subsection{Photocatalytic Activity}

For the degradation of Rhodamine $6 \mathrm{G}$, the synthesized $\mathrm{ZnO}-\mathrm{ZrO}_{2} \mathrm{NC}$ was employed, and $20 \mathrm{mg}$ of $\mathrm{ZnO}-\mathrm{ZrO}_{2} \mathrm{NC}$ was added to $50 \mathrm{~mL}$ of Rhodamine $6 \mathrm{G}$ solution for each experiment. The experiment was subjected to a simulated sun light lamp, model US800, $250 \mathrm{~W}$ with the wavelength range of $280-800 \mathrm{~nm}$, after $30 \mathrm{~min}$ of stirring in the dark. The variations in absorbance maxima as a function of time were detected using a double beam spectrophotometer after a particular time period.

\section{Conclusions}

Ficus elastica extract was used for the synthesis of $\mathrm{ZnO}-\mathrm{ZrO}_{2} \mathrm{NC}$ due to its non-toxicity and eco-friendly nature. The prepared $\mathrm{ZnO}-\mathrm{ZrO}_{2} \mathrm{NC}$ was calcined at different temperatures to determine the effect of calcination on photodegradation and physicochemical properties. The XRD result shows that the degree of crystallinity along the crystallite sizes increases with increasing calcination, and maximum crystallinity was reported at elevated temperatures. The SEM analysis revealed that the variation in the surface properties occurred due to the dehydration and rearrangement of particles under the influence of heat, which resulted in the degeneration of highly agglomerated samples (compact solids) into small particles. The elemental composition study revealed that the desired elements were present in the sample. The physicochemical study revealed the synthesis of a $\mathrm{ZnO}-\mathrm{ZrO}_{2}$ 
heterojunction where the counterparts $\left(\mathrm{ZnO}\right.$ and $\left.\mathrm{ZrO}_{2}\right)$ have different crystal and optical properties. The changes in the degradation of dye with increasing calcination temperature are attributed to the stability of the sample, phase transformation from amorphous to crystalline phase, and variation in structural properties. The stability test shows that the $\mathrm{ZnO}-\mathrm{ZrO}{ }_{2}$ calcined at $900{ }^{\circ} \mathrm{C}$ was the most stable catalyst, followed by the one calcined at $100{ }^{\circ} \mathrm{C}$, whereas the catalyst calcined at $600{ }^{\circ} \mathrm{C}$ showed the lowest photocatalytic activity.

Author Contributions: Conceptualization, S.H.; methodology, S.H. and H.A.; software, P.A.; validation, M.U.K., P.A. and W.R.; formal analysis, H.A.; investigation, N.S., H.O. and M.I.S.; resources, M.I.S.; data curation, M.W., H.O. and S.H.; writing—original draft preparation, S.H., H.A. and W.R.; writing-review and editing, M.U.K., H.O., P.A., I.U.D. and S.H.; visualization, M.W. and W.R.; supervision, S.H. and H.O.; project administration, S.H.; funding acquisition, H.O. and S.A. All authors have read and agreed to the published version of the manuscript.

Funding: We deeply acknowledge Taif University for supporting the researchers through Taif University Researchers Supporting Project number (TURSP-2020/287), Taif University, Taif, Saudi Arabia.

Data Availability Statement: All the data is available within the manuscript.

Acknowledgments: We deeply acknowledge Taif University for supporting the researchers through Taif University Researchers Supporting Project number (TURSP-2020/287), Taif University, Taif, Saudi Arabia.

Conflicts of Interest: The authors declare no conflict of interest.

\section{References}

1. Das, R.; Sypu, V.S.; Paumo, H.K.; Bhaumik, M.; Maharaj, V.; Maity, A. Silver decorated magnetic nanocomposite (Fe3O4@PPyMAA/Ag) as highly active catalyst towards reduction of 4-nitrophenol and toxic organic dyes. Appl. Catal. B Environ. 2019, 244, 546-558. [CrossRef]

2. Ismail, M.; Akhtar, K.; Khan, M.I.; Kamal, T.; Khan, M.A.; Asiri, A.M.; Seo, J.; Khan, S.B. Pollution, Toxicity and Carcinogenicity of Organic Dyes and their Catalytic Bio-Remediation. Curr. Pharm. Des. 2019, 25, 3645-3663. [CrossRef]

3. Gusain, R.; Gupta, K.; Joshi, P.; Khatri, O.P. Adsorptive removal and photocatalytic degradation of organic pollutants using metal oxides and their composites: A comprehensive review. Adv. Colloid Interface Sci. 2019, 272, 102009. [CrossRef] [PubMed]

4. Hunge, Y.M.; Yadav, A.A.; Mahadik, M.A.; Bulakhe, R.N.; Shim, J.J.; Mathe, V.L.; Bhosale, C.H. Degradation of organic dyes using spray deposited nanocrystalline strati fi ed WO 3 / TiO 2 photoelectrodes under sunlight illumination. Opt. Mater. 2018, 76, 260-270. [CrossRef]

5. Kaykhaii, M.; Sasani, M.; Marghzari, S. Removal of Dyes from the Environment by Adsorption Process. Chem. Mater. Eng. 2018, 6, 31-35. [CrossRef]

6. Hunge, Y.M.; Yadav, A.A.; Kang, S.W.; Kim, H. Photocatalytic degradation of tetracycline antibiotics using hydrothermally synthesized two-dimensional molybdenum disulfide/titanium dioxide composites. J. Colloid Interface Sci. 2022, 606, 454-463. [CrossRef]

7. Karuppaiah, S.; Annamalai, R.; Muthuraj, A.; Kesavan, S.; Palani, R.; Ponnusamy, S.; Nagarajan, E.R.; Meenakshisundaram, S. Efficient photocatalytic degradation of ciprofloxacin and bisphenol A under visible light using Gd 2 WO 6 loaded ZnO/bentonite nanocomposite. Appl. Surf. Sci. 2019, 481, 1109-1119. [CrossRef]

8. Chiu, Y.-H.; Chang, T.-F.M.; Chen, C.-Y.; Sone, M.; Hsu, Y.-J. Mechanistic Insights into Photodegradation of Organic Dyes Using Heterostructure Photocatalysts. Catalysts 2019, 9, 430. [CrossRef]

9. Shah, J.H.; Fiaz, M.; Athar, M.; Ali, J.; Rubab, M.; Mehmood, R.; Jamil, S.U.U.; Djellabi, R. Facile synthesis of N/B-double-doped Mn2O3 and WO3 nanoparticles for dye degradation under visible light. Environ. Technol. 2020, 41, 2372-2381. [CrossRef]

10. Hunge, Y.M.; Uchida, A.; Tominaga, Y.; Fujii, Y.; Yadav, A.A.; Kang, S.W.; Suzuki, N.; Shitanda, I.; Kondo, T.; Itagaki, M.; et al. Visible light-assisted photocatalysis using spherical-shaped bivo4 photocatalyst. Catalysts 2021, 11, 460. [CrossRef]

11. Yadav, A.A.; Kang, S.W.; Hunge, Y.M. Photocatalytic degradation of Rhodamine B using graphitic carbon nitride photocatalyst. J. Mater. Sci. Mater. Electron. 2021, 32, 15577-15585. [CrossRef]

12. Dashairya, L.; Sharma, M.; Basu, S.; Saha, P. SnS2/RGO based nanocomposite for efficient photocatalytic degradation of toxic industrial dyes under visible-light irradiation. J. Alloys Compd. 2019, 774, 625-636. [CrossRef]

13. David, L.; Moldovan, B. Green Synthesis of Biogenic Silver Nanoparticles for Efficient Catalytic Removal of Harmful Organic Dyes. Nanomaterials 2020, 10, 202. [CrossRef]

14. Wang, Y.; Hu, K.; Yang, Z.; Ye, C.; Li, X.; Yan, K. Facile Synthesis of Porous ZnO Nanoparticles Efficient for Photocatalytic Degradation of Biomass-Derived Bisphenol A Under Simulated Sunlight Irradiation. Front. Bioeng. Biotechnol. 2021, 8, 616780. [CrossRef] [PubMed] 
15. Uribe López, M.C.; Alvarez Lemus, M.A.; Hidalgo, M.C.; López González, R.; Quintana Owen, P.; Oros-Ruiz, S.; Uribe López, S.A.; Acosta, J. Synthesis and characterization of $\mathrm{ZnO}-\mathrm{ZrO}_{2}$ nanocomposites for photocatalytic degradation and mineralization of phenol. J. Nanomater. 2019, 2019, 1015876. [CrossRef]

16. Długosz, O.; Szostak, K.; Banach, M. Photocatalytic properties of zirconium oxide-zinc oxide nanoparticles synthesised using microwave irradiation. Appl. Nanosci. 2020, 10, 941-954. [CrossRef]

17. Aghabeygi, S.; Khademi-Shamami, M. $\mathrm{ZnO} / \mathrm{ZrO}_{2}$ nanocomposite: Sonosynthesis, characterization and its application for wastewater treatment. Ultrason. Sonochem. 2018, 41, 458-465. [CrossRef]

18. Khataee, A.; Gholami, P.; Kayan, B.; Kalderis, D.; Dinpazhoh, L.; Akay, S. Synthesis of ZrO2 nanoparticles on pumice and tuff for sonocatalytic degradation of rifampin. Ultrason. Sonochem. 2018, 48, 349-361. [CrossRef]

19. Precious Ayanwale, A.; Reyes-López, S.Y. ZrO2-ZnO Nanoparticles as Antibacterial Agents. ACS Omega 2019, 4, 19216-19224. [CrossRef]

20. Midala, I.H.; Kamari, H.M.; Al-Hada, N.M.; Tim, C.K.; Muhamad, S.; Hamza, A.M.; Abubakar, T.R.; Nuhu, I.M. Structural, morphological and optical properties of $(\mathrm{ZnO}) 0.2$ (ZrO2)0.8 nanoparticles. Appl. Phys. A Mater. Sci. Process. 2019, $125,668$. [CrossRef]

21. Haq, S.; Rehman, W.; Waseem, M.; Meynen, V.; Awan, S.U.; Saeed, S.; Iqbal, N. Fabrication of pure and moxifloxacin functionalized silver oxide nanoparticles for photocatalytic and antimicrobial activity. J. Photochem. Photobiol. B Biol. 2018, 186, 116-124. [CrossRef] [PubMed]

22. Obaidullah, M.; Furusawa, T.; Siddiquey, I.A.; Bahadur, N.M.; Sato, M.; Suzuki, N. A fast and facile microwave irradiation method for the synthesis of $\mathrm{ZnO} @ Z \mathrm{ZrO} 2$ core-shell nanocomposites and the investigation of their optical properties. Adv. Powder Technol. 2018, 29, 1804-1811. [CrossRef]

23. Sherly, E.D.; Vijaya, J.J.; Kennedy, L.J.; Meenakshisundaram, A.; Lavanya, M. A comparative study of the effects of CuO, NiO, $\mathrm{ZrO} 2$ and $\mathrm{CeO} 2$ coupling on the photocatalytic activity and characteristics of ZnO. Korean J. Chem. Eng. 2016, 33, 1431-1440. [CrossRef]

24. Bibi, N.; Haq, S.; Rehman, W.; Waseem, M.; Rehman, M.U.; Shah, A.; Khan, B.; Rasheed, P. Low temperature fabrication of SnO2, $\mathrm{ZnO}$ and $\mathrm{Zn} 2 \mathrm{SnO} 4$ nanostructures for the degradation of Rhodamine 6G: Characterization. Biointerface Res. Appl. Chem. 2020, 10, 5895-5900.

25. Shah, A.; Haq, S.; Rehman, W.; Muhammad, W.; Shoukat, S.; Rehman, M. Photocatalytic and antibacterial activities of Paeonia emodi mediated silver oxide nanoparticles. Mater. Res. Express 2019, 6, 045045. [CrossRef]

26. Rasheed, P.; Haq, S.; Waseem, M.; Rehman, S.U.; Rehman, W.; Bibi, N.; Shah, S.A.A. Green synthesis of vanadium oxide-zirconium oxide nanocomposite for the degradation of methyl orange and picloram. Mater. Res. Express 2020, 7. [CrossRef]

27. Haq, S.; Shoukat, S.; Rehman, W.; Waseem, M.; Shah, A. Green fabrication and physicochemical investigations of zinc-cobalt oxide nanocomposite for wastewater treatment. J. Mol. Liq. 2020, 318, 114260. [CrossRef]

28. Basahel, S.N.; Ali, T.T.; Mokhtar, M.; Narasimharao, K. Influence of crystal structure of nanosized $\mathrm{ZrO}_{2}$ on photocatalytic degradation of methyl orange. Nanoscale Res. Lett. 2015, 10, 73. [CrossRef]

29. Anju, S.G.; Yesodharan, S.; Yesodharan, E.P. Zinc oxide mediated sonophotocatalytic degradation of phenol in water. Chem. Eng. J. 2012, 189-190, 84-93. [CrossRef]

30. Farhan Hanafi, M.; Sapawe, N. Effect of Calcination Temperature on the Structure and Catalytic Performance of $\mathrm{ZrO}_{2} \mathrm{Catalyst}_{\mathrm{n}}$ Phenol Degradation. Mater. Today Proc. 2019, 19, 1533-1536. [CrossRef]

31. Movahedi, M.; Mahjoub, A.R.; Janitabar-Darzi, S. Photodegradation of Congo red in aqueous solution on $\mathrm{ZnO}$ as an alternative catalyst to $\mathrm{TiO}_{2}$. J. Iran. Chem. Soc. 2009, 6, 570-577. [CrossRef]

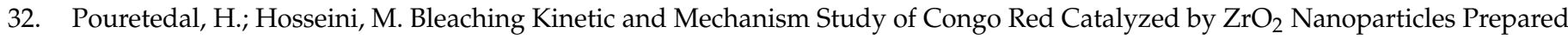
by Using a Simple Precipitation Method. Acta Chim. Slov. 2010, 57, 415-423. [PubMed]

33. Hassan, N.S.; Jalil, A.A.; Aziz, F.F.A.; Fauzi, A.A.; Azami, M.S.; Jusoh, N.W.C. Tailoring the Silica Amount in Stabilizing the Tetragonal Phase of Zirconia for Enhanced Photodegradation of 2-Chlorophenol. Top. Catal. 2020, 63, 1145-1156. [CrossRef]

34. Zyoud, A.H.; Asaad, S.; Zyoud, S.H.; Zyoud, S.H.; Helal, M.H.; Qamhieh, N.; Hajamohideen, A.R.; Hilal, H.S. Raw clay supported $\mathrm{ZnO}$ nanoparticles in photodegradation of 2-chlorophenol under direct solar radiations. J. Environ. Chem. Eng. 2020, 8, 104227. [CrossRef]

35. Satpal, S.B.; Athawale, A.A. Synthesis of ZnO and Nd Doped ZnO Polyscales for Removal of Rhodamine 6G Dye under UV Light Irradiation. Mater. Res. Bull. 2018, 5, 085501. [CrossRef]

36. Haq, S.; Rehman, W.; Waseem, M.; Meynen, V.; Awan, S.U.; Khan, A.R.; Hussain, S.; Zain-ul-Abdin; Din, S.U.; Hafeez, M.; et al. Effect of Annealing Temperature on Structural Phase Transformations and Band Gap Reduction for Photocatalytic Activity of Mesopores TiO2 Nanocatalysts. J. Inorg. Organomet. Polym. Mater. 2021, 31, 1312-1322. [CrossRef]

37. Ahmad, M.; Rehman, W.; Khan, M.M.; Qureshi, M.T.; Gul, A.; Haq, S.; Ullah, R.; Rab, A.; Menaa, F. Phytogenic fabrication of ZnO and gold decorated ZnO nanoparticles for photocatalytic degradation of Rhodamine B. J. Environ. Chem. Eng. 2021, 9, 104725. [CrossRef]

38. Zada, N.; Saeed, K.; Khan, I. Decolorization of Rhodamine B dye by using multiwalled carbon nanotubes/Co-Ti oxides nanocomposite and Co-Ti oxides as photocatalysts. Appl. Water Sci. 2020, 10, 40. [CrossRef]

39. Kaur, J.; Bansal, S.; Singhal, S. Photocatalytic degradation of methyl orange using ZnO nanopowders synthesized via thermal decomposition of oxalate precursor method. Phys. B Condens. Matter 2013, 416, 33-38. [CrossRef] 